\title{
TATA LAKSANA PENGUKURAN OS FEMORALIS DENGAN METODE ORTHOROENTGENOGRAFI
}

\author{
Cicillia Artitin ${ }^{1 *}$, Debi Alfino ${ }^{2}$ \\ ${ }^{1,2}$ Prodi D III Radiologi, Fakultas Vokasi, Universitas Baiturrahmah, Padang \\ Email: cicillia.artitin.ca@gmail.com
}

\begin{abstract}
ABSTRAK
Femur adalah tulang terpanjang dari tubuh, berupa tulang pipa dan mempunyai sebuah batang dan dua ujung. Indikasi pemeriksaannya yaitu kelainan kongetial pada tulang, terjadinya fraktur atau fissure dan beberapa khasus lainnya seperti fraktur spiral yang menyebabkan pemendekan tumpang tindihnya fragmen, atau fraktur dapat kominuta (hancur menjadi beberapa keping) dan mengakibatkan ukuran, bentuk, dan panjang dari tulang tersebut mengalami perubahan. Metode orthoroentgenografi adalah suatu metode yang memberikan kepastian dalam pengukuran dari panjang tulang secara lebih detail, akurat dan spesifik pada tulang yang akan diukur. Tujuan penelitian ini adalah untuk mengetahui tatalaksana yang benar dalam pengukuran Os Femur dengan metode Orthoroentgenografi. Penelitian ini dilaksanakan pada bulan Mei 2019 di Rumah Sakit Khusus Bedah Ropanasuri Padang. Penelitian ini dilakukan terhadap satu orang pasien laki-laki, umur 18 tahun dan tinggi badan $172 \mathrm{~cm}$ dengan klinis post orif pada femur. Hasil penelitian pengukuran os femoralis yaitu didapatkan panjang pada bagian medial femur $28 \mathrm{~cm}$, pada bagian distal femur $11,9 \mathrm{~cm}$, pada bagian proximal femur 4,6 cm. Hasil keseluruhan pengukuran didapatkan 44,5 cm. Dapat diketahui bahwa metode orthoroentgenografi adalah metode yang secara tepat dapat membuktikan pengukuran femur yang tepat dan akurat pada pemeriksaan os femoralis.
\end{abstract}

Kata kunci: os femoralis, metode orthoroentgenografi, radiografi

\begin{abstract}
The Femur is the longest bone of the body. The bone is a pipe and has a stem and two ends, with an indication of examination for the presence of congenital abnormalities in the bone, the occurrence of a fracture or fissure and several other cases sich as spiral fractures that cause shortening of overlapping fragment, or communal fracture (broken into pieces) an resulting in changes in size, shape and length of the bone. Orthorontgenografi method is a method that provides certainty in measuring the length of the bone in moral detail, accurate and specifications on the bone to be measured. The purpose of this study is know the measurement results os femur by using orthorontgenografi method. The research is being done in May 2019 at the Ropanosuri Padang Special Surgical Hospital. This study was conducted on one male patient, 18 years old and $172 \mathrm{~cm}$ tall with clinical post orif on the femur. The results of the study of measurement of femoral bone with orthoroentgenography method were obtained at length in the medial part of the femur is $28 \mathrm{~cm}$, in the distal part of the
\end{abstract}




\begin{abstract}
femur is $11.9 \mathrm{~cm}$, in the proximal part of the femur is $4,6 \mathrm{~cm}$. The overall results of the measurements obtained $44.5 \mathrm{~cm}$. From the discussion above, it can be seen that the method of orthoroentgenography is a method that can accurately prove the correct and accurate measurement of the femur on the examination of the femoral bone.
\end{abstract}

Keywords: os femoralis, orthoroentgenografi method, radiographic

\title{
PENDAHULUAN
}

Pemeriksaan Radiodiagnostik adalah pemeriksaan pada suatu objek dengan menggunakan sinar-X yang memiliki daya tembus begitu tinggi sehingga organ yang terletak didalam tubuh dapat diperlihatkan melalui gambaran Radiografi (Rasad, 2005). Salah satu jenis pemeriksaan adalah teknik pemeriksaan radiografi pada $O s$ femur. Femur atau tulang paha adalah tulang terpanjang dari tubuh, tulang ini bersendi dengan acetabulum dalam persendian panggul dan dari sini menjulur ke lutut dan membuat sendi dengan tibia (Pearce, 2013). Tulangnya berupa tulang pipa dan mempunyai sebuah batang dan dua ujung, dengan indikasi pemeriksaan adanya kelainan kongetial pada tulang, terjadinya fraktur atau fissure dan beberapa kasus lainnya seperti fraktur spiral yang menyebabkan pemendekan tumpang tindihnya fragmen, atau fraktur dapat kominuta (hancur menjadi beberapa keping) dan mengakibatkan ukuran, bentuk dan panjang dari tulang tersebut mengalami perubahan (Moore, 2003).

Gambaran radiografi yang didapat secara khusus juga mampu sebagai alat ukur untuk pengontrolan pertumbuhan tulang femur dengan indikasi tersebut. Metode orthoroentgenografi adalah suatu metode yang memberikan kepastian dalam pengukuran dari panjang tulang secara lebih detail, akurat dan spesifik pada tulang yang akan diukur. Pengukuran berfungsi juga sebagai gambaran perbandingan panjang tulang atau pemeriksaan kontrol pertumbuhan objek yang tidak normal seperti pada bagian tulang persendian (Curry, 1990). Manfaat metode ini adalah dapat mengukuran tulang panjang lebih mendetail dan tepat pada sasaran tulang yang diukur, sehingga akan jelas ukuran bagian spesifik pada struktur tulang yang akan diperiksa. Dari hasil pengukuran dalam bentuk film rontgen, akan didapat gambaran yang tidak bisa dilihat dengan jelas dengan pemeriksaan biasa, dikarenakan bagian tersebut akan tertutup oleh kulit yang menyulitkan untuk mengukur dan mencari batas tulang yang akan diukur secara pasti, seperti pada bagian tulang persendian (Ballinger, 2003). Adapun tujuan dan manfaat penelitian ini adalah untuk mengetahui tata laksana yang benar dan hasil pengukuran os femoralis yang tepat dan akurat dengan metode Orthoroentgenografi.

\section{METODOLOGI PENELITIAN}

Jenis penelitian ini adalah jenis kuantitatif dengan eksperimen sederhana. Penelitian dilakukan di Unit Radiologi Rumah Sakit Khusus Bedah Ropanasuri Padang pada bulan Mei 2019. Objek penelitian dilakukan terhadap orang pasien laki laki yang berumur 18 tahun, dengan tinggi badan sekitar $172 \mathrm{~cm}$, dengan klinis post orif. Alat yang digunakan adalah Pesawat sinar-x, Kaset dan Film Radiografi, mistar khusus (panjang $30 \mathrm{~cm}$ ) dan pita pengukur.

\section{HASIL DAN PEMBAHASAN}

Telah dilakukan tata laksana os femoralis metode orthorentgenografi terhadap pasien Tn.G, umur 18 tahun, jenis kelamin laki-laki dengan tinggi badan $172 \mathrm{~cm}$ di Rumah Sakit Ropanasuri. Dengan prosedur proyeksi untuk distal femur adalah bagian distal femur diberi penanda dan ditempatkan 
dipertengahan kaset dengan batas bawah 2 inchi kebawah dari pertengahan lutut dan batas atas 2-4 inchi keatas dari pertengahan lutut. Letakkan mistar khusus disamping objek dengan bagian ujung mistar sejajar dengan batas atas objek yang telah diberi penanda. Cental Ray diatur tegak lurus pada objek dengan central point pada pertengahan knee joint atau lutut pasien (Gambar 1).

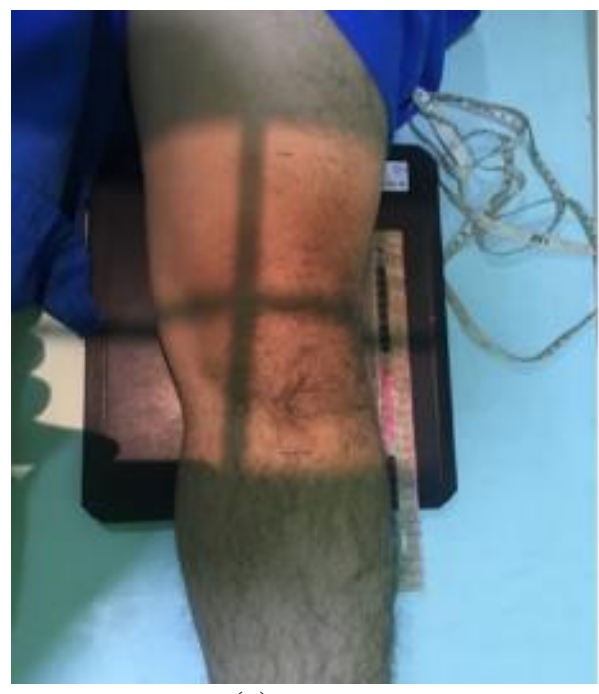

(a)

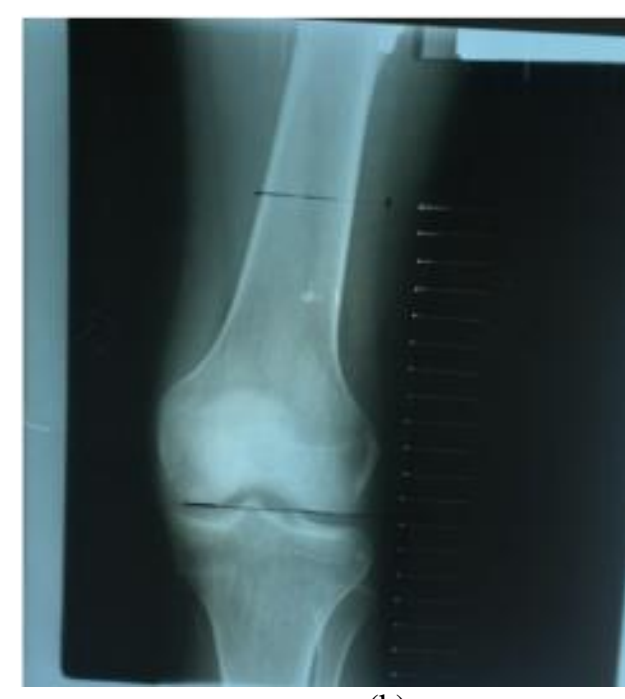

(b)

Gambar 1. Hasil Distal Femur (a) Posisi Objek, (b) Hasil Radiograf

Gambar 1 menunjukkan hasil radiograf distal femur yang memperlihatkan garis pengukuran. Tampak distal femur, proximal tibia fibula, epicondylus lateralis dan medialis femur, condyus lateralis dan medialis femur, patella yang superposisi, serta space knee joint terbuka. Pada hasil pengukuran distal femur didapatkan ukuran bagian distal femur $11,9 \mathrm{~cm}$.

Selanjutnya dilakukan proyeksi pada bagian proximal femur. Dengan prosedur sebagai berikut: 1) Berikan penanda pada bagian proximal femur yang ditempatkan di pertengahan kaset pada 2 inchi medial dari MSP ke SIAS dengan batas atas SIAS dan batas bawah 4-6 inchi kebawah dari SIAS, 2) Letakkan mistar khusus disamping objek dengan bagian ujung mistar sejajar dengan batas bawah objek yang telah diberi penanda, 3) Central ray diatur tegak lurus objek, dan central point pada pertengahan objek (sesuai dengan Gambar 2).

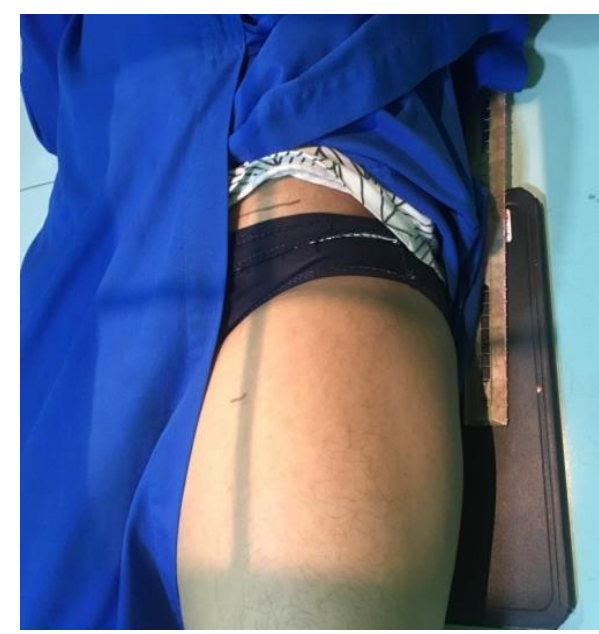

(a)

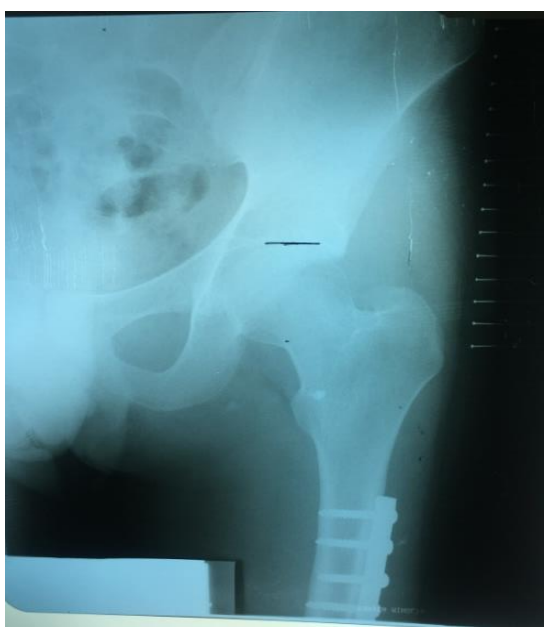

(b)

Gambar 2. Hasil Proximal Femur (a) Posisi Objek, (b) Hasil Radiograf 
Pada hasil radiograf proximal femur, terlihat garis pengukuran, tampak proximal femur, acetabulum, caput femur, colum femur, trochanter mayor dan minor femur. Hasil pengukuran proximal femur didapatkan ukuran bagian proximal femur sepanjang $4,6 \mathrm{~cm}$. Selanjutnya dilakukan pengukuran pada bagian medial dengan menggunakan pita ukur yang dapat dilihat pada Gambar 3 dibawah ini.

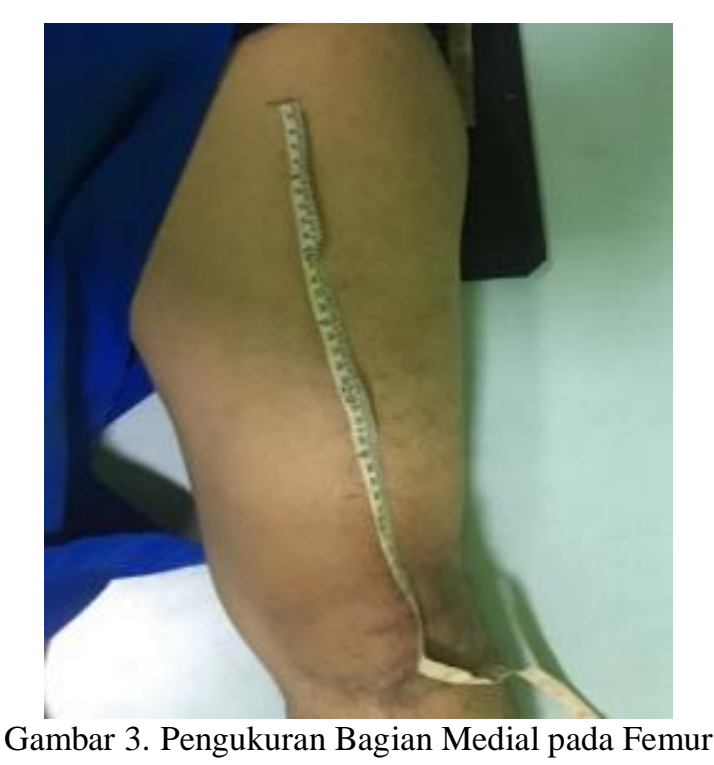

Pada Gambar 3 diatas, mengukur panjang bagian medial (pertengahan) femur dengan menggunakan pita ukur pada bagian yang sudah ditandai dari batas bawah proximal femur sampai ke batas atas distal femur. Pada hasil pengukuran medial femur didapatkan ukuran bagian medial femur $28 \mathrm{~cm}$.

Sehingga hasil pengukuran dengan metode orthoroentgenografi secara keseluruhan menunjukkan bahwa pengukuran bagian medial femur sebesar $28 \mathrm{~cm}$, pengukuran pada radiograf distal femur sebesar 11,9 cm, pengukuran pada radiograf proximal femur sebesar 4,6 cm, dan hasil seluruh pengukuran, 44,5 $\mathrm{cm}$. Menurut Moore (2003), panjang tulang femur sekitar seperempat dari tinggi badan seseorang. Berdasarkan data pasien dengan inisial Tn. $\mathrm{G}$ dengan tinggi badan $172 \mathrm{~cm}$, jika dikaitkan dengan teori Moore maka didapatkan panjang femur pasien tersebut adalah $43 \mathrm{~cm}$.

\section{KESIMPULAN}

Berdasarkan hasil penelitian dapat disimpulkan bahwa hasil pengukuran os femoralis dengan metode orthoroentgenografi didapatkan panjang hasil os femoralis yaitu sebesar $44,5 \mathrm{~cm}$. Dan dapat disimpulkan bahwa metode orthoroentgenografi adalah metode yang dapat membuktikan pengukuran femur secara tepat dan akurat pada pemeriksaan os femoralis.

\section{UCAPAN TERIMA KASIH}

Terimkasih banyak kepada Rumah Sakit Khusus Bedah Ropanasuri Padang yang telah memberi izin untuk melakukan penelitian ini. 


\section{DAFTAR PUSTAKA}

Ballinger, P. (2003). Radiographic Position and Radiologic Procedures . USA: Mosby Company.

Curry, T. (1990). Christensen's Introduction to the Physics of Diagnostic Radiology. USA: Lea and Febiger.

Moore, K. L. (2003). Anatomi Berorientasi Klinis. Jakarta: Erlangga.

Pearce, E. C. (2013). Anatomi dan Fisiologi Untuk Paramedis. Jakarta: Gramedia.

Rasad, S. (2005). Radiologi Diagnostik. Jakarta: Badan Penerbit FKUI. 